\title{
THE CORRELATION BETWEEN MOTIVATION AND ACHIEVEMENT OF SIXTH YEAR PUPILS AT SDN INPRES 3 BIROBULI IN LEARNING ENGLISH
}

\author{
Sari Wulandari \\ Fakultas Keguruan dan Ilmu Pendidikan, Universitas Muhammadiyah Palu \\ E-mail: rhiewoel@gmail.com
}

\begin{abstract}
This research was a correlation study with two variables - variable $\mathrm{X}$ standing for motivation and variable Y standing for achievement. The purpose of this study was to find out is there any positive correlation between motivation and achievement in leraning English especially for the pupils of grade six at SDN inpres 3 Birobuli. The data were collected by using documentation and questionnaire. Then, they were analyzed descriptively. Through questionnaire and pupils' learning result, it was found that the level of correlation between variable $\mathrm{X}$ and $\mathrm{Y}$ was strong enough, there was positive correlation between variable $\mathrm{X}$ and $\mathrm{Y}$ since the value of $\mathrm{r}$-counted $(0,475)$ was higher than the value of r-table $(0,235)$. Meaning the higher motivation they get the better achievement they have.
\end{abstract}

Key words : correlation, motivation, learning.

\section{INTRODUCTION}

Learning English is not easy for pupils who live in the country in which English is taught as a foreign language. In the process of learning, we can find that many pupils are successful while some others are not. It can be seen from their learning achievement. The question that may arise around us is why some pupils are successful while others are not even though they are learning in the same circumstance, place, and taught by the same teacher. English learning process can be influenced by internal and external factors.

The internal factors consist of physiological and fatigue limitation of the learners. The physiological factors include their health and physical defects, the psychological factors are IQ (intelligence), interest, attention, aptitude, motivation, readiness and maturity while the fatigue factors include physical exhaustion and spiritual exhaustion. 
Another factor that influences the English learning process is external factors such as: the parents' education, family situation, and economy, the relationship of member of family, parents' understanding, care and control and cultural background. The school factors such as: method, curriculum, the relationship between the teacher and the pupils, school discipline, school instrument, school schedule, standard of lesson, situation of building, learning method, and home assignment. The society factors include pupils's activity in the society such as taking English course and joining group of discussion.

The result of the teaching learning process can be seen from the pupils' academic achievement. Academic achievement is a result which has been achieved by an individual after he or she accomplished some evaluation and assignment. It can be concluded that academic achievement is the result which has been achieved by someone after he or she followed certain subject at school. There are several factors affecting pupils' achievement in learning English, mmotivation is one of them. Where motivation is a word used to a general influence of an individual to act in learning process. We have to understand that when someone begins to learn something new especially English language, he/she need more motivation to make them more spirit. Because English is difficult, so in learning it the pupils needs support from whole their environment.

\section{Research Question}

The researcher wants to inverstigate pupil's motivation aspect toward learning English and its influence on their English achievement. Therefore the research question of this research is formulated as follows: "is there any positive correlation between motivation and achievement in learning English of the sixt year pupils at SDN inpres 3 Birobuli?” 


\section{METHODOLOGY}

This research was correlation research. Correlation design was procedures in quantitative research in which inverstigator measure the degree of relationship between two or more variable using the statistical procedures of correlational analysis. The purpose of this study was to find out is there any positive correlation between motivation and achievement in learning English especially for the pupils of grade six at SDN Inpres 3 Birobuli. The data were collected by using documentation and questionnaire. Then, they were analyzed descriptively.

\section{FINDING AND DISCUSSION}

The description of the data presented according to the procedures or instrument used; the documentation and questionnaire. All the data were analyzed by categorizing, comparing and synthesizing. All the data from different instruments were crossed checked in order to get trustworthiness.

Pupils' English result documentation taken from pupils' rapports. Pupils' score in their rapports were their result of learning. The pupils' score could be seen in the table 1.1 and 1.2 below

Table 1.1 : The pupils learning result in English (with KKM:75

Class six A

\begin{tabular}{|l|c|c|c|}
\hline No & Initial & $\begin{array}{c}\text { English Score } \\
\text { (result) }\end{array}$ & Success/failed \\
\hline 1. & Muh & 77 & Successful \\
\hline 2. & And & 75 & Successful \\
\hline 3. & Mar & 79 & Successful \\
\hline 4. & Moh & 80 & Successful \\
\hline 5. & Mut & 80 & Successful \\
\hline 6. & May & 75 & Successful \\
\hline 7. & Aan & 77 & Successful \\
\hline 8. & Ach & 77 & Successful \\
\hline 9. & Stev & 78 & Successful \\
\hline 10. & Ard & 83 & Successful \\
\hline 11. & Dim & 75 & Successful \\
\hline
\end{tabular}




\begin{tabular}{|l|c|l|l|}
\hline 12. & Rah & 76 & Successful \\
\hline 13. & Sol & 80 & Successful \\
\hline 14. & Rah & 80 & Successful \\
\hline 15. & Wah & 77 & Successful \\
\hline 16. & Khof & 85 & Successful \\
\hline 17. & Din & 89 & Successful \\
\hline 18. & Ran & 86 & Successful \\
\hline 19 & Sri & 79 & Successful \\
\hline 20. & Nur & 88 & Successful \\
\hline 21. & Sal & 75 & Successful \\
\hline 22. & Eka & 89 & Successful \\
\hline 23. & Nad & 89 & Successful \\
\hline 24. & Ind & 80 & Successful \\
\hline 25. & Shof & 87 & Successful \\
\hline 26. & Wid & 76 & Successful \\
\hline 27. & Lis & 87 & Successful \\
\hline 28. & Shaf & 75 & Successful \\
\hline 29. & Afi & 79 & Successful \\
\hline 30. & Mey & 75 & Successful \\
\hline 31. & Chel & 85 & Successful \\
\hline 32. & Tia & 80 & Successful \\
\hline 33. & Giv & 90 & Successful \\
\hline 34. & Jua & 80 & Successful \\
\hline 35. & Ded & 80 & Successful \\
\hline
\end{tabular}

Table 1.2: The pupils learning result in English (with KKM 75)

Class six B

\begin{tabular}{|l|c|c|c|}
\hline No & Initial & $\begin{array}{c}\text { English Score } \\
\text { (result) }\end{array}$ & Success/failed \\
\hline 1. & M. fad & 77 & Successful \\
\hline 2. & Ryn & 75 & Successful \\
\hline 3. & Irf & 79 & Successful \\
\hline 4. & Sig & 80 & Successful \\
\hline 5. & Ali & 80 & Successful \\
\hline 6. & Mak & 75 & Successful \\
\hline 7. & Faz & 77 & Successful \\
\hline 8. & Daf & 77 & Successful \\
\hline 9. & Isw & 78 & Successful \\
\hline 10. & Muh & 83 & Successful \\
\hline
\end{tabular}




\begin{tabular}{|l|c|l|l|}
\hline 11. & Put & 75 & Successful \\
\hline 12. & Hen & 76 & Successful \\
\hline 13. & Far & 80 & Successful \\
\hline 14. & M.fah & 80 & Successful \\
\hline 15. & Ilh & 77 & Successful \\
\hline 16. & Akri & 85 & Successful \\
\hline 17. & Far & 89 & Successful \\
\hline 18. & Ang & 86 & Successful \\
\hline 19 & Dik & 79 & Successful \\
\hline 20. & Cha & 88 & Successful \\
\hline 21. & Ade & 75 & Successful \\
\hline 22. & Tia & 89 & Successful \\
\hline 23. & Mar & 89 & Successful \\
\hline 24. & Hik & 80 & Successful \\
\hline 25. & Wahy & 87 & Successful \\
\hline 26. & Nuz & 76 & Successful \\
\hline 27. & Win & 87 & Successful \\
\hline 28. & Ana & 75 & Successful \\
\hline 29. & Cla & 79 & Successful \\
\hline 30. & Fit & 75 & Successful \\
\hline 31. & Yun & 85 & Successful \\
\hline 32. & Ama & 80 & Successful \\
\hline 33. & Fat & 90 & Successful \\
\hline 34. & Gre & 80 & Successful \\
\hline 35. & Mur & 80 & Successful \\
\hline
\end{tabular}

The result of the student's achievement in English has been reported in their rapport which has been explained in table 1.1 and 1.2. In this table we can see that all of the pupils were succesful in learning English because all of them got the score up higher than the minimum score. In the next table was explained about the pupils result in questionnaire. There ten item of questionnaire that should be answer by the pupils and the result of it analyzed quantitatively.

After analyzing the result of pupils' achievement in English and the result of questionnaire, the researcher analyzed the data by using the formula or correlation, and she got the result was 0.475 . It means that the result of $r$-counted was 0.475 . 
In order to know the significant correlation between variable $\mathrm{X}$ (motivation) and variable $\mathrm{Y}$ (Achievement) the researcher using the 5\% level of significant to compare with the r-table. It was found that r-table is 0.235 . It then proved that the value of r-counted (0.475) was higher than the value of r-table $(0.235)$. Then the researcher drew the conclusion that the alternative hypothesis (Ha) was accepted, while the null hypothesis (Ho) was rejected, meaning there was correlation between motivation and achievement.

To know whether the correlation between variable $\mathrm{X}$ and variable $\mathrm{Y}$ is significant or not, the value of t-counted was compare to the value of t-table. If the value of $\mathrm{t}$ - counted is higher than the value of t-table, then there is significant correlation between variable $\mathrm{X}$ and variable $\mathrm{Y}$. Conversely, if the value of t-table is higher than the value of t-counted (4.45), then there is no significant correlation between variable $\mathrm{X}$ and variable $\mathrm{Y}$.

By using 0.05 level of significant $(\alpha)$, and 68 degree of freedom $(\mathrm{df}=\mathrm{n}-2=$ $70-2=68$ ), the value of $t$-table then could not be found in the table. Therefore, the only way to gain the value was to apply interpolation computation by involving the closest degree of freedom available in the table -60 and $120 \mathrm{df}$. The result of the interpolation computation was 1.6577 .

Since the value of t-counted (4.45) was higher than the value of t-table (1.6577), the significant was positive, meaning there was significant correlation between variable $\mathrm{X}$ (motivation) and variable $\mathrm{Y}$ (achievement). After analyzing all the data of the achievement and questionnaire it can be conclude that there was positive correlation between motivation and achievement in learning.

\section{CONCLUSION}

Based on the previous chapter and research findings, the researcher would like to conclude as follows : Through questionnaire and pupils' learning result, it was found that the level of correlation between variable $\mathrm{X}$ and variable $\mathrm{Y}$ was strong enough, there was positive correlation between variable $\mathrm{X}$ and variable $\mathrm{Y}$ since the 
value of r-counted (0.475) was higher than the value of r-table (0.235). It can answer the research question and can proud the objective of the research that there is positive correlation between motivation and achievement of sixth year pupils of SDN Inpres 3 Birobuli. It can prove the hypothesis, means that there is significant correlation between motivation and achievement in learning English. In which the alternative hypothesis (Ha) was accepted while the null hypothesis (Ho) was rejected.

\section{References}

Akib, M., Haryanto, H., Iskandar, I., \& Patak, A. A. (2018). Investigating the motivation, participation, and achievement of students. International Journal of Humanities and Innovation (IJHI), 1(2), 17-27.

Albert . (1989). Motivation and attitude in foreign language learning. New York

Alexander kjerulf (2011) http://positivesharing.com/2010/12/why-motivation-bypizza-doesnt-work/

Bloom, L.M (1870). Language Development: Form and Function in Emerging Grammars. Cambridge, Mass: MIT Press.

Brophy, Jere (1997). Motivating pupils to learn. Guilford. CT: McGraw-Hill. (ISBN: 0070081980).

Chomsky (1981). Second Language Learning: a psycholinguistic perspective. Kinsela Press.

Fincham, F \& Cain, K. M. (1986). Learned helplessness in humans: A developmental analysis. Developmental Review, 6, 301-333.

Goldberg, M. D. \& Cornell, D. G. (1994). The influence of intrinsic motivation and self-concept on academic achievement in second-and third-grade pupils. Journal for the education of the Gifted, 21(2), 179-205.

Grandlund. (1981). The achievement motive. New York. Irvingnon publishers.

Him (1971). Learning a second Language through command. Modern language Journal vol. 58, nos.1-2, pp. 24-32

Kartono. (1985). Sikap Manusia: perubahan serta pengukurannya. Jakarta. Ghalia Figley, C. (2002): The Green Cross Project., Camden, Maine, copyright 1995-2006. Skinner, B.F (1957). Verbal Behaviour. New York: Appleton-Century-Crofts. 